\title{
WPŁYW CIĘCIA CESARSKIEGO NA ROZWÓJ PSYCHOMOTORYCZNY DZIECKA
}

\section{EFFECT OF CAESAREAN SECTION ON PSYCHOMOTOR DEVELOPMENT OF THE CHILD}

\author{
Joanna Moćkun, Jolanta Olszewska \\ Katedra Pielęgniarstwa Ginekologiczno-Położniczego \\ Gdański Uniwersytet Medyczny
}

DOI: https://doi.org/10.20883/pielpol.2017.20

\begin{abstract}
STRESZCZENIE
Cięcie cesarskie (CC) to najczęściej wykonywany operacyjny zabieg położniczy na całym świecie. Według zaleceń WHO tylko $10-15 \%$ wszystkich porodów powinno kończyć się CC z powodów medycznych, tymczasem w 2008 r. odsetek cesarskich cięć wynosił w Polsce 30\%.

Cięcie cesarskie ma niewątpliwie wiele zalet, m.in. zmniejsza ryzyko wystąpienia zagrażającej zamartwicy płodu, zespołu zachłyśnięcia smółką i urazu okołoporodowego. Większość kobiet jednak nie zdaje sobie sprawy z zagrożeń, które niesie ono za sobą. Z badań wynika, że dzieci urodzone poprzez CC znajdują się w grupie zwiększonego ryzyka wystąpienia zaburzeń w funkcjonowaniu układu oddechowego, pokarmowego, zwiększonego ryzyka wystąpienia otyłości, a także alergii. Nie bez znaczenia jest także wpływ operacyjnego zakończenia ciąży na psychikę dziecka. Wzrost liczby przeprowadzanych CC jako alternatywy dla porodu fizjologicznego (PSN) nie jest niepokojący, jeśli wynika z aktualnych wskazań lekarskich. Alarmujący jest natomiast wzrost liczby cięć przeprowadzanych na skutek wyboru dokonywanego przez kobietę, często nie w pełni świadomą późniejszych zagrożeń.
\end{abstract}

SŁOWA KLUCZOWE: poród, poród naturalny, cięcie cesarskie, rozwój dziecka, noworodki, karmienie piersią.

\section{Cięcie cesarskie}

Cięcie cesarskie (CC) jest jedną z niewielu procedur medycznych, które przekształciły się nie tylko w obszarze techniki zabiegu czy wskazań do jego wykonania, ale również skutków, jakie niesie za sobą ten sposób rozwiązania ciąży. CC przekształciło się z zabiegu wykonywanego tylko na zmarłych ciężarnych w operację wybieraną przez ciężarną jako alternatywny sposób zakończenia ciąży.

CC jest to chirurgiczne przyjęcie porodu poprzez nacięcie ścian jamy brzusznej oraz macicy. Zaleca się wykonywanie CC w znieczuleniu podpajęczynówkowym. Znieczulenie ogólne podawane jest najczęściej tylko w wyjątkowych przypadkach, np. stany nagłe, ciężkie uszkodzenie płodu, prośba pacjentki, zagrożenie życia matki [2].

\begin{abstract}
Caesarean section (CC) is the most commonly performed obstetrical operating procedure in the world. According to the WHO recommendations only 10-15 percent of all births should end with CC for medical reasons, while in 2008 the number of cesarean deliveries in Poland amounted to 30 percent.

The cesarean section has undoubtedly many advantages, among others reduces the risk of threatening fetal asphyxia, meconium aspiration syndrome and perinatal injury. Most women, however, do not realize the risks cesarean sections imply. Research shows that children born through $\mathrm{CC}$ are in a group of an increased risk of disturbances in the functioning of the respiratory system, digestive system, increased risk of obesity and allergies. Not without significance is the impact of operational termination of pregnancy on the child's psyche. The increase in the number of CC carried out as an alternative to the physiological childbirth (PSN) is not disturbing if it is the result of the current medical indication. Alarming is, however, an increase in the number of cuts carried out due to the choice made by women, who often is not fully aware of the risks.
\end{abstract}

KEYWORDS: parturition, natural childbirth, cesarean section, child development, newborn, breast feeding.

\section{Współczesne wskazania do operacyjnego zakończenia porodu}

CC, zgodnie z przedstawioną wcześniej definicją, jest operacją, a więc wiąże się z dużo większą możliwością wystąpienia powikłań (nawet od 3 do 10 razy) w porównaniu z porodem fizjologicznym. W związku z powyższym każdy przypadek powinien być udokumentowany wskazaniami medycznymi [3], które należy obecnie rozumieć jako celowość działania uzasadniającego optymalne rozstrzygnięcie dla matki i płodu.

W piśmiennictwie medycznym znaleźć można różne podziały wskazań do operacyjnego zakończenia porodu, co wynika z faktu, że czynniki wpływające na formułowanie wskazań do CC są ciągle aktualizowane i zmieniane [4]. W podziale wskazań rekomendowanym przez Polskie Towarzystwo Ginekologiczne (PTG) nie 
odnajdziemy CC „na życzenie”, bez konkretnych wskazań medycznych [5], chociaż odsetek CC wykonanych na prośbę matki plasuje się na poziomie 4-18\% wszystkich CC na całym świecie. Natomiast w USA jest to wielkość w granicach 2,6-5,5\%. Potwierdza to fakt, że „życzenie” matki ma coraz większy wpływ na decyzje lekarzy położników [6].

Specjaliści z dziedziny neonatologii całkowicie akceptują wskazania rekomendowane przez PTG, podkreślając przy tym, że zakończenie ciąży CC nie jest naturalnym sposobem porodu [5].

\section{Zaburzenia w rozwoju psychomotorycznym dziecka wynikające z zakończenia ciąży cięciem cesarskim}

Już od momentu narodzin widoczne są wyraźne różnice między noworodkiem urodzonym siłami natury a urodzonym poprzez CC (głównie elektywne), w tym m.in.: różnice $w$ pracy płuc czy serca, tendencje do utrzymywania glukozy na niższym poziomie czy niższa temperatura ciała noworodka urodzonego przez elektywne CC, utrzymująca się przez pierwsze 1,5 godziny od urodzenia. Wyniki przytoczonych badań są wciąż w wielu przypadkach jedynie hipotezami, wymagającymi potwierdzenia, stąd też należy zachować ostrożność podczas przeprowadzania analiz i interpretacji wyników badań w tych przypadkach, kiedy okres pomiędzy pierwszym a ponownym badaniem wybranej grupy badawczej wyniósł mniej niż 15 lat [7].

\section{Zmiana DNA dziecka}

Według badań opublikowanych w 2009 r. przez szwedzkich naukowców CC wpływa na modyfikacje chemiczne w DNA noworodka i to właśnie te zmiany najprawdopodobniej przyczyniają się do częstszej zachorowalności na choroby immunologiczne, m.in. na astmę, przez dzieci urodzone cięciem cesarskim. W badaniach zaobserwowano modyfikację w pobranych z pępowiny noworodka leukocytach, polegające na wzmożonych procesach modyfikacji kodu DNA. Przyczyną tych zmian jest stres porodowy, przewyższający inne wydarzenia życiowe. Potężna aktywacja wydzielania adrenaliny pobudza zarówno system ochronny organizmu, jak i centralny układ nerwowy płodu do optymalnego przygotowania do życia poza organizmem matki. Wielkość i rodzaj stresu są odmienne w zależności od sposobu zakończenia ciąży. Stres u noworodków urodzonych fizjologicznie jest stopniowy, natomiast noworodki z elektywnego CC narażone są na stres nagły. Eksperymenty dowodzą, że nagły stres okołoporodowy dotyczący dzieci urodzonych przez CC nie tylko zwiększa ryzyko wystąpienia astmy, alergii czy cukrzycy, ale również może trwale zmienić reakcje behawioralne i neuroendokrynne. Badania te dowiodły także, że dzieci urodzone przez CC mają niższy stopień metylacji DNA 3-5 dni po urodzeniu, co sugeruje opóźnienia w adaptacji poporodowej. Są to pierwsze badania dotyczące związku pomiędzy elektywnym CC i metylacją DNA w porównaniu z PSN, dlatego badacze podkreślają, że aby dokładnie określić, jak długo utrzymują się chemiczne modyfikacje DNA, konieczna jest kontynuacja tych badań [8].

\section{Zaburzenia układu oddechowego}

Noworodki urodzone przez CC nie spełniają wszystkich zasadniczych warunków niezbędnych do rozpoczęcia prawidłowej czynności oddechowej oraz właściwej adaptacji układu oddechowego w pierwszej minucie po przyjściu na świat [5]. U dzieci z CC, nawet 2 godziny po urodzeniu, obserwuje się znacznie mniejszą niż u dzieci urodzonych drogą pochwową objętość oddechową, podatność dynamiczną oraz wentylację minutową. Główną przyczyną takiego stanu jest brak stresu związanego z porodem fizjologicznym, podczas którego następuje uwolnienie amin katecholowych do krążenia płodowego. Zbyt niskie stężenie adrenaliny we krwi dziecka urodzonego poprzez CC jest przyczyną zmniejszenia szybkości uwalniania surfaktantu oraz pojawienia się zespołu zaburzeń oddychania [9]. U dzieci urodzonych poprzez elektywne CC nie zostaje usunięty płyn owodniowy z płuc z powodu braku kompresj klatki piersiowej. Efekt kompresji klatki piersiowej jest niezbędny do prawidłowego oddychania [10]. W związku z tym większość dzieci urodzonych elektywnym CC wymaga sztucznej wentylacji oraz resuscytacji od razu po przyjściu na świat [9]

Jak wynika z badań przeprowadzonych w 2005 r. przez Kornacką i Kufel dodatkowo u dzieci urodzonych przez elektywne CC zauważa się większe ryzyko wystąpienia przejściowej zadyszki (tachypnoe) - o 4,3\% więcej przypadków niemowląt z tachypnoe urodzonych przez elektywne CC [5].

Natomiast z danych opublikowanych w 2006 r. przez Narodowy Instytut Zdrowia z USA wynika, że na milion porodów zakończonych elektywnym CC 11 tys noworodków wykazywało zaburzenia w oddychaniu. W porównaniu z taką samą liczbą porodów fizjologicznych było to o 8476 więcej [5].

Ciężkie przypadki zaburzeń układu oddechowego wymagają zazwyczaj przyjęcia noworodka na oddział intensywnej terapii noworodka oraz zastosowania sztucznej wentylacji. Powoduje to ryzyko wystąpienia powikłań oraz konieczność oddzielenia nowo narodzonego dziecka od matki, a tym samym chociażby utrud- 
nienie karmienia piersią [11]. W konsekwencji ma to także wpływ na rozwój psychiczny dziecka - ze względu na utrudnienie kontaktu „skóra do skóry” [5].

\section{Astma}

Współcześnie obserwuje się wzrost zachorowalności na astmę. W Polsce choruje na nią około $5 \%$ dorosłych i $9 \%$ dzieci [12]. Fińscy naukowcy w swoich badaniach wykazali istotny wpływ sposobu przyjścia na świat na ryzyko wystąpienia astmy oraz chorób alergicznych w wieku dorosłym. Badania przeprowadzono na osobach urodzonych w Finlandii w 1966 r. po ukończeniu przez nie 31. roku życia. Astmę wykazano u 13,6\% osób urodzonych w wyniku CC i u 4,5\% osób urodzonych drogą pochwową. Wynika z tego, że ryzyko zachorowania na tę chorobę u osób z pierwszej grupy jest 3,02-krotnie większe. Ci sami naukowcy zaobserwowali także, że zakończenie ciąży CC wiązało się z o $40 \%$ wyższym ryzykiem astmy w wieku 7 lat w porównaniu z osobami urodzonymi przez PSN [13].

\section{Zaburzenia układu pokarmowego}

Układ pokarmowy dziecka i wszystkie błony śluzowe są jałowe do momentu przyjścia dziecka na świat. Dziecko przychodzące na świat drogą pochwową rodzi się w pobliżu odbytu matki, co stanowi pewną gwarancję zasiedlenia układu pokarmowego noworodka przyjaznymi i wielorakimi bakteriami, których nosicielką jest rodząca. Urodzone w sterylnej sali operacyjnej dziecko pozbawione jest tych „dobrych, matczynych” bakterii, więc najprawdopodobniej pierwszymi drobnoustrojami, z którymi się spotka, będą te pochodzące ze szpitalnego powietrza oraz rąk personelu medycznego. Oczywistym jest więc, że biorąc pod uwagę kryterium bakteriologiczne, istnieje duża różnica pomiędzy PSN a zakończeniem ciąży poprzez CC [7].

Odmienna sytuacja zachodzi u noworodków z CC wykonanego po długotrwałym odpływaniu płynu owodniowego. Do kolonizacji układu pokarmowego dochodzi wówczas wewnątrzmacicznie, z pochwy matki, a CC nie zakłóca właściwej kolonizacji przewodu pokarmowego i jest ono uważane za bezpieczniejsze dla dziecka [9].

Drobnoustroje zawarte w jelitach, już od pierwszych chwil po porodzie, spełniają bardzo ważną funkcję. Po pierwsze, stanowią barierę ochronną przed niebezpiecznymi bakteriami chorobotwórczymi, służą detoksykacji oraz są niezbędne do produkcji witamin, m.in. biotyny. Po drugie, odpowiadają one za rozwój układu odpornościowego.

W badaniach bakteriologicznych kału niemowląt u dzieci urodzonych poprzez CC przed 2. miesiącem życia nie stwierdzono kolonizacji bakterii Bacteroides sp., natomiast ich ilość w 6. miesiącu była o połowę mniejsza niż u dzieci z PSN. Również ilość bakterii Lactobacillus i Bifidobacter u dzieci z CC była niższa. Drobnoustroje zasiedlające przewód pokarmowy noworodka jako pierwsze stają się jego florą bakteryjną na następne lata i mają znaczny wpływ na metabolizm organizmu [5].

\section{Alergie pokarmowe}

Amerykańscy naukowcy dowiedli, że sposób przyjścia na świat może mieć znaczny wpływ na występowanie alergii. Zgodnie z ich hipotezą ciągły wzrost ilości zachorowań na choroby alergiczne spowodowany jest zmniejszeniem narażenia na mikroorganizmy we wczesnym okresie życia. Elementy flory jelitowej wykazały wpływ na odpowiedź immunologiczną organizmu. Pomimo iż flora jelitowa przystosowuje się do zmian przez całe nasze życie, najłatwiej zmienna jest chwilę po urodzeniu, ze względu na kolonizację bakterii we wcześniej sterylnych jelitach [14].

$\mathrm{U}$ dzieci urodzonych przez CC i tych urodzonych przez PSN występują różnice w kolonizacji flory bakteryjnej. Sugeruje się, że może mieć to wpływ na zachowanie równowagi pomiędzy limfocytami TH1 i TH2 we wczesnym dzieciństwie, które z kolei mogą być związane z występowaniem chorób alergicznych w dorosłym życiu. Badania fińskich naukowców nie potwierdziły jednak związku CC z ryzykiem wystąpienia atopii, wyprysku atopowego czy kataru siennego [13].

Podobną próbę podjęli naukowcy z Uniwersytetu Kalifornijskiego w San Francisco. Po analizie obecności limfocytów T w krwi pępowinowej dowiedli, że u dzieci, które urodzone zostały poprzez CC, limfocyty słabiej hamowały komórki odporności wydzielające interleukinę 13 i to one są odpowiedzialne za reakcje alergiczne. Podkreślają oni jednak, że aby dokładniej zrozumieć mechanizmy odpowiedzialne za związek pomiędzy odpornością dziecka a rodzajem zakończenia ciąży, potrzebne są dalsze badania [15].

\section{Problemy z otyłością}

Według raportu International Day for the Evaluation of Abdominal Obesity opublikowanego w 2007 r., a dokumentującego wyniki badania przeprowadzonego na grupie 5371 Polaków, na otyłość bądź nadwagę cierpi $67,6 \%$ badanych pomiędzy 16 . a 51 . rokiem życia. Z analizy wynika, że coraz większą grupę stanowią dzieci w wieku 13-15 lat, u których aż w 8,8\% stwierdzono nadwagę, natomiast w 4,5\% - otyłość [16].

Problemem otyłości u dzieci zajmowali się chińscy naukowcy. Przeanalizowali oni wyniki dziewięciu badań, w których wzięło udział ponad 200 tys. osób. Badania związane były z rosnącą tendencją do wzrostu wagi 
w trzech przedziałach wiekowych: od 3. do 8. roku życia, od 9. do 18. roku życia i od 19. roku życia. Jednym z elementów, który został uwzględniony w analizie, była waga urodzeniowa dziecka, która według opinii naukowców może mieć wpływ na skłonność do nadwagi bądź otyłości. Przytoczone badania wykazały wyższe ryzyko otyłości bądź nadwagi u osób urodzonych poprzez CC w stosunku do urodzonych PSN: w dzieciństwie o $32 \%$, w okresie nastoletnim o $24 \%$, w wieku dorosłym aż o $50 \%$. Według autorów analizy wyniki te są warte uwagi zarówno ze względu na ciągle rosnący odsetek ludzi otyłych w społeczeństwie, jak i wzrastającą liczbę ciąż kończonych CC. Badania nie dały jednoznacznej odpowiedzi na pytanie, dlaczego CC może mieć wpływ na skłonność do wzrostu wagi. Przyczyn upatruje się, podobnie jak w przypadku chociażby alergii, m.in. w ograniczeniu kontaktu dziecka urodzonego operacyjnie z mikroflorą dróg rodnych matki. Ponadto coraz więcej badań wykazuje, że na przemianę materii, procesy wchłaniania i przetwarzania składników pokarmowych wpływ mają bakterie żyjące w jelitach ludzkich. Duże znaczenie może mieć również fakt, że kobiety rodzące poprzez CC rzadziej karmią piersią, co także może zwiększać skłonność do tycia. Badania wykazały także, że we krwi pępowinowej dzieci urodzonych poprzez CC występuje niższe stężenie hormonów odpowiedzialnych za regulację masy ciała [17].

\section{Próchnica}

Jednym z najważniejszych czynników ryzyka wystąpienia próchnicy we wczesnym dzieciństwie jest duża ilość drobnoustrojów tworzących próchnicę oraz wczesna kolonizacja jamy ustnej. Najnowsze doniesienia wskazują na znaczący wpływ porodu poprzez CC na pojawienie się próchnicy u dzieci w wieku lat 3. Noworodek urodzony w ten sposób nie nabywa naturalnej odporności organizmu, na skutek czego powstaje możliwość szybszego zasiedlenia jamy ustnej przez paciorkowce Streptococcus mutants.

Badacze z Uniwersytetu Medycznego w Łodzi przebadali grupę 3-latków, 68 z nich przyszło na świat poprzez PSN, a 34 - poprzez CC. Analiza badań oceniających intensywność próchnicy wykazała, że u dzieci urodzonych poprzez CC wartość wskaźnika wynosiła 7,53 i była o 4,54 wyższa niż u dzieci urodzonych fizjologicznie. Jak wynika z badań, również ilość bakterii S. mutans oraz Lactobacillus sp. obecnych w ślinie dzieci urodzonych CC była znacznie wyższa.

Przeprowadzone statystyki wykazały istotną zależność pomiędzy cięciem cesarskim a ilością próchnicotwórczych bakterii obecnych w ślinie badanych 3-latków oraz zaawansowaniem próchnicy nazębnej. Przedstawione wyniki badań zgodnie z sugestią auto- rów pozwalają zaliczyć CC do czynników ryzyka rozwoju próchnicy w okresie wczesnego dzieciństwa [18].

\section{Podsumowanie}

W ostatnich latach, tak w Polsce, jak i na świecie, obserwuje się pokaźny wzrost odsetka cięć cesarskich, z 13,3\% w 1994 r. do 30\% w 2008 r., oraz znaczną liberalizację wskazań do tego zabiegu, co wpływa na liczbę ciąż zakończonych porodem operacyjnym. Aktualne badania dowodzą, że nie bez znaczenia pozostaje sposób przyjścia na świat dziecka na jego stan zdrowia i dalszy rozwój. Uważa się, że cięcie cesarskie wpływa m.in. na zmianę DNA dziecka, zaburzenia układu oddechowego, pokarmowego, alergie, cukrzycę, otyłość, próchnicę nazębną oraz zaburzenia w rozwoju psychicznym. Nie bez znaczenia pozostaje też wpływ cięcia cesarskiego na karmienie piersią. Z analizy dostępnych źródeł wynika, że sposób zakończenia ciąży rzutuje na długość karmienia piersią oraz ilość endorfin zawartych w mleku. Niestety w związku z faktem, że cięcie cesarskie jest stosunkowo nowym zjawiskiem w medycynie, znaczna część badań dotyczących jego wpływu na rozwój psychomotoryczny dziecka wymaga dalszych analiz w celu potwierdzenia stawianych dziś hipotez.

\section{Piśmiennictwo}

1. Mazurek-Kantor J, Sawicki W, Gawryluk A et al. Analiza częstości cięć cesarskich wykonanych w latach 1986-2007 w materiale własnym. Perinatol Neonatol Ginekol. 2008; 1(1): 45-46.

2. Baston $\mathrm{H}$, Hall J, Henley-Einion A. Podstawy położnictwa najważniejsze zagadnienia. Wrocław: Elsevier Urban \& Partner; 2011. 176.

3. Guzikowski W, Więcek J, Kowalczyk D. Wskazania do cięcia cesarskiego w Szpitalu Ginekologiczno-Położniczym i Noworodków im. dr. S. Mossora w Opolu w 2007 roku. Perinatol Neonatol Ginekol. 2008; 1(1): 38-40.

4. Piasek G, Radomski P, Adamczyk-Gruszka O, Maj M et al. Analiza porównawcza wskazań do cięć cesarskich w latach 1980-1990 oraz 1993-2001 w Wojewódzkim Szpitalu Zespolonym w Kielcach. Studia Med. 2011: 13-19.

5. Kornacka MK, Kufel K. Cięcie cesarskie a stan noworodka. Ginekol Pol. 2011: 612-617.

6. Ramachandrappa A, Jain L. Elective Cesarean Section: It's Impact on Neonatal Respiratory Outcome. Clin Perinatol. 2008; 35(2): 373-vii.

7. Odent M. Cesarskie cięcie a poród naturalny. Wątpliwości, konsekwencje, wyzwania. Wrocław: Fundacja Kobieta i Natura; 2010. 52-76.

8. Schlinzig T, Johansson S, Gunnar A et al. Norman M. Epigenetic modulation at birth - altered DNA-methylation in white blood cells after Caesarean section. Acta Paediatr. 2009; 98(7): 1096-1099.

9. Bręborowicz G. Położnictwo. Tom III. Operacje w położnictwie. Warszawa: PZWL; 2012. 7-280.

10. Kolås T, Saugstad D, Daltveit AK et al. Planned cesarean versus planned vaginal delivery at term: Comparison of newborn infant outcomes. Am J Obstet Gynecol. 2006; 12 : 1542. 
11. Fogelson NS, Menard MK et al. Neonatal impact of elective repeat cesarean delivery at term: a comment on patient choice cesarean delivery. Am J Obstet Gynecol. 2005; 5: 1433-1436.

12. Chazan R. Pneumonologia i alergologia. Wybrane jednostki chorobowe. Bielsko-Biała: Wyd. Med. alfa-medica press; 2010: 13.

13. Xu B, Pekkanen J, Hartikainen AL et al. Caesarean section and risk of asthma and allergy in adulthood. J Allergy Clin Immunol. 2001; 4: 732-733.

14. Renz-Polster H, David MR, Buist AS. Caesarean section delivery and risk of allergic disorders in childhood. Clin Exp Allergy. 2005; 11: 1466-1472.

15. Cięcie cesarskie powodem częstszych alergii u dzieci, http://www.rynekzdrowia.pl/Neonatologia/Ciecie-cesarskie-powodem-czestszych-alergii-u-dzieci,212,20.html (data dostępu: 26.04.2016).

16. Bodera P, Filipek B, Jędrzejczak M, Ruxer J, Sapa J, Zahorska-Markiewicz B. Profilaktyka oraz leczenie nadwagi i otyłości. Warszawa: Biblioteka Naukowa Czasopisma Aptekarskiego; 2010. 5.

17. Li H, Zhou Y, Liu J. Cesarean section might moderately increase offspring obesity risk. Am J Clin Nutr. 2012; 7: 893-899.
18. Szczepańska J, Szydłowska-Walendowska B, Pawłowska E, Lubowiedzka-Gontarek B. Liczebność bakterii Streptococcus mutans i Lactobacillus sp. w ślinie 3-letnich dzieci urodzonych przez cesarskie cięcie. Czas Stomatol. 2009: $712-721$.

Artykuł przyjęty do redakcji: 04.07.2016

Artykuł przyjęty do publikacji: 19.09.2016

Źródło finansowania: Praca nie jest finansowana z żadnego źródła. Konflikt interesów: Autorzy deklarują brak konfliktu interesów.

\section{Adres do korespondencji:}

Joanna Moćkun

ul. Srebrna $38 / 42$

80-180 Gdańsk

tel. kom.: 722396442

e-mail: jmockun@gumed.edu.pl

Katedra Pielęgniarstwa Ginekologiczno-Położniczego

Gdański Uniwersytet Medyczny 